IRA-International Journal of Management \& Social Sciences

ISSN 2455-2267; Vol.10, Issue 03 (March 2018)

Pg. no. 94-99.

Institute of Research Advances

http://research-advances.org/index.php/RAJMSS

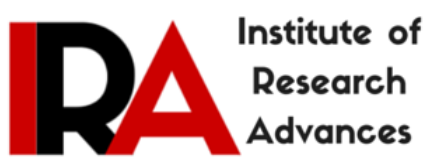

\title{
Identity of Ao-Naga and Sümi-Naga Women as Gleaned from Folklores
}

\author{
Dr. Resenmenla Longchar ${ }^{1 \#} \&$ Dr. H. Salome Kinny ${ }^{2}$ \\ ${ }^{1}$ Asst. Professor, Department of History, ICFAI University, Nagaland, India. \\ ${ }^{2}$ Asst. Professor, Department of English, ICFAI University, Nagaland, India.
}

\#corresponding author.

Type of Review: Peer Reviewed.

DOI: http://dx.doi.org/10.21013/jmss.v10.n3.p1

How to cite this paper:

Longchar, R., Kinny, H.S. (2018). Identity of Ao-Naga and Sümi-Naga Women as Gleaned from Folklores. IRA-International Journal of Management \& Social Sciences (ISSN 2455-2267), 10(3), 9499. doi:http://dx.doi.org/10.21013/jmss.v10.n3.p1

(C) Institute of Research Advances.

(cc) BY-NC

This work is licensed under a Creative Commons Attribution-Non Commercial 4.0 International License subject to proper citation to the publication source of the work.

Disclaimer: The scholarly papers as reviewed and published by the Institute of Research Advances (IRA) are the views and opinions of their respective authors and are not the views or opinions of the IRA. The IRA disclaims of any harm or loss caused due to the published content to any party.

Institute of Research Advances is an institutional publisher member of Publishers Inter Linking Association Inc. (PILA-CrossRef), USA. The institute is an institutional signatory to the Budapest Open Access Initiative, Hungary advocating the open access of scientific and scholarly knowledge. The Institute is a registered content provider under Open Access Initiative Protocol for Metadata Harvesting (OAI-PMH).

The journal is indexed \& included in WorldCat Discovery Service (USA), CrossRef Metadata Search (USA), WorldCat (USA), OCLC (USA), Open J-Gate (India), EZB (Germany) Scilit (Switzerland), Airiti (China), Bielefeld Academic Search Engine (BASE) of Bielefeld University, Germany, PKP Index of Simon Fraser University, Canada. 


\begin{abstract}
The word identity has drawn a lot of attention to itself more so in the present age where everyone seems to be in a quest to establish their own identity. This quest for identity is not an alien concept to Naga society which comprises of sixteen officially recognized communities. These communities rely upon their own set of folklores to glean their past. Folklores are a strong medium through which most of the traditional beliefs and cultural practices are embodied. It is a reflection of the past through which the identity of the community can be gleaned. Folklores are not mere spinning of tales to glorify one's own community, but are narratives of the communities who follow oral-tradition. This paper attempts to glean the identity of Ao-Naga and Sümi-Naga women through their respective folklores. Ao-Naga and Sümi-Naga are two strong communities residing in Nagaland. Both the communities have rich folklores falling into different genres. A striking feature of most folktales is the way details are presented-the name of the village, location and presence of evidence in the present times suggesting the validity of the events in the folktales. After the construction of identity is done, this paper will compare the identity of women of these two communities. Women of both these communities have come a long way from what they were in the past. As the third and final component of this paper, it will analyse whether women are still under grip of their past identity or whether they have moved away from it to build a new identity for themselves in the $21^{\text {st }}$ Century. This paper will further examine the identity of women in the $21^{\text {st }}$ Century in the light of their past as constructed from the folklores.
\end{abstract}

Key words: Women, Identity, Folklores, Ao-Naga, Sümi-Naga.

I

Nagas are one among the many ethnic groups of the North-eastern India that geographically share the borders of four countries- China, Myanmar, Bangladesh and Bhutan of Asia. Like any other tribals in India, the Nagas have their own rich cultural heritage preserved in the form of oral traditions and artifacts and the Nagas prevail upon their lore, the verbal and non verbal expressive behaviour deposited in the mnemonics of the people which is learnt and transmitted orally through the generations. The lore embodies the knowledge, beliefs and the institutions that guided the people and communities to retain their identities, their 'selves' from erosion and invasion despite changes in time and space. Their folk (oral) lore is a rich source for reconstructing their histories and encompasses a wide variety of genres which establish the distinctiveness and identity among the other tribal communities in Nagaland. Story telling is an innate impulse and an accepted expressive behaviour among the people. Especially in oral societies, like the Nagas where the communication and transmission of knowledge is based on orality and mnemonics, narratives are the only channels through which one can articulate with the other throughout the generations. By rendering tales narrators find meaning to their own lives and also to their respective culture and environment in which they are born and raised.

The family of the Nagas is patriarchal in character where father or husband is the head of the family. The institution of patriarchy emerged to pattern family as a basic unit of society. In a patriarchal set up, the male in different gender relations operates hegemonic roles in the family and plays a vital role in decision making in every aspect of family life basing on their respective gender norms. Sons succeed not only property and assets of their parents but also the duties and responsibilities of the family and name of the clan.

II

In traditional society, the prestige of an Ao family depended upon the virility of men who were supposed to perform headhunting. Despite the domestic chore, women played major role in agricultural operations. ${ }^{1}$ The folktales show how women and men participate in jhum cultivation and show the problems with regard to child rearing at home during the times of agricultural operations. Men controlled the community resource and the social systems and women took care of the family as well as the domestic economy and the production. ${ }^{2}$ Women are exclusive custodians of weaving and spinning and this job is forbidden for men. According to J.P.Mills, "A poor chance of getting a good husband would be an Ao girl who did not know how to spin and weave and make for the family. It is one of her most important duties, which it is absolutely forbidden for a man to share in Ao-Naga society." ${ }^{3}$ The identity of the Ao-Naga women is established through the following points.

Tattooing: In the past, tattooing was the major determinant of identity for the Ao girls for it symbolizes the beginning of the process of puberty, the stage at which they can claim for membership in their community. 
Tattooing is a specialized craft and art designed and executed by specialists from community. In Ao-Naga society, only old women who have expertise chose the profession of tattooing. It is a hereditary profession following in the female line and it was more or less mandatory for a daughter of a tattooist to follow her mother's profession. It is because they believed that if the profession is not practiced by the successors, the art would soon disappear and make them poor and disgraceful. The entry of men was strictly prohibited. Only the eligible girls were entitled to become a member of institution (girl's dormitory), once the girl goes through all the rites that are fixed by the community. The girl remains in the dormitory till she gets married. Different designs of tattooing were placed on different parts of the body of the girls. The following narrative held that according to the tradition different designs to differentiate the groups in the village.

\section{Narrative 1: Designs of tattoos}

In past, the young girls would sleep in the Tsük (girl's dormitory) at night. Girls from both rich and poor families would meet each other and they spent time singing and narrating stories. Amongst the group, there were two girls. One belongs to a rich family from Chungli clan and the other girl from a poor family of Mongsen clan who was intelligent, beautiful and popular with many of the other girls. The rich girl cultivates jealousy with the poor girl and she started to dislike her. The rich girl started to make fun of the poor girl in front of the other girls. Since Mongsen girl is very beautiful, so out of jealousy the mother of the rich girl put a criss-cross tattoo on the Mongsen girl and a parallel tattoo on her daughter. But after the wound on the leg of the Mongsen girl is healed it is much admired. From that day on the villagers started tattooing and different patterns of tattoos were applied for the two groups. The patterns of their tattoos give identity and even the boys found it helpful in distinguishing the girls they admired. ${ }^{4}$

Clothing: As women's clothing was concerned; wife and daughter were depended on the husband/father richness. Whose father/husband had done Mithun ${ }^{5}$ sacrifice wears a different pattern on her skirt and besides clothing; they wear crystals earrings, brass rings, hornbill feathers, brass bracelets which clearly indicate that they belong to the rich and wealthy family. Poor and ordinary women were not entitled to wear such ceremonial clothes even during festivals.

Inheritance: In a family, when a daughter is married she goes out of her father's family and comes under the authority of the husband. The children of the daughter are considered as the children of a family of other clan. Therefore the daughter and her children have no place in her father's family. The daughters are regarded as subordinate members and do not become co-owners with sons and do not inherit property of the family. The property belonging to the mother after her death can be distributed among her daughters. Tug for property sometimes occur within the families with the parties playing tricks regarding the property. This situation is clearly shown in the following tale.

\section{Narrative 2: Distribution of property}

Once upon a time, there was a rich family. Unfortunately, the mother died leaving her two daughters with her father Tamayangba. Before she died many clothes, necklaces and ornaments were left with Tamayangba for their daughters. Since he was getting old, he decided to share the property of his wife to his daughters. He constantly worried that his daughters may fight after his death for the property of their mother. So he chalked out a plan. He pretended as if he was dead due to illness while his daughters arranged for his memorial service. They then started to mourn over their father's dead body (When a person dies, people mourn by singing songs of praise about him). The first daughter sings to his father, "oh Apa Tamayangba yatem dangko kongto kongra den dang chowng nupasü" (oh Father Tamayangba, why are you leaving us. When you were alive you always wanted to have food with dry meat in the evenings. The father then understood from the song of her first daughter that her mourning reflected more accusation rather than concern for him even in the matters of food. He then listened to the younger daughter's song. She sang, "Father Tamayangba when you cross Meyutsüngba's (Lord of justice) place, shout and go down saying, 'Yangrenmenla's (her name) father is coming down." After listening to his daughters' song the father comes to the realization that his younger daughter loved him more than the elder daughter. So after they had finished singing, he got up from his coffin much to their astonishment. Later the father distributed the property to them. The younger daughter received all the good clothes and the beautiful ornaments whereas the elder daughter received only the ugly ones because she was rude towards her father. ${ }^{6}$ 
Since the Ao family succession is through the male line, sons, brothers, nephews, cousins are the order of preference for inheritance of properties. Sons born from different wives are brothers and they have legal right to inherit their father's ancestral property. The father of the family has absolute power over the family property and the sons and grandsons have no right to claim partition of properties against the father. In a family, if there is no son and many daughters then (in the present times) the father distributes the lands or house which has been bought by him to his daughters before he dies. For this, witnesses are needed. Witness can be someone who is the eldest from the kins or from the clan. ${ }^{7}$ An Ao woman inherits the belongings of her mother, sister and maternal aunt. If her husband dies leaving to her the minor children, she become the owner of the family property till they become matured. There is no question of division of property between the mother and the son. The son will claim the property of the father. The Ao-Naga society strictly regulated roles and relations among men and women in their patriarchal system through their established customs and practices to endure their kinship and inheritance.

Debt: Customary law imposes the responsibility of debt clearance on debtor. If the father fails to pay back the loan, his successor, be it his wife or uterine son or distant heir should clear it off. According to Ao custom, direct heir is liable to pay the debt with full interest but the distant heir is to pay the debt of the deceased with half of the interest only. ${ }^{8}$ Direct heir includes son, grandson and great grandson and also brother of the deceased; distant heir includes cousin, nephew, uncle and other paternal blood relations. According to the custom, debt will continue to last generation to generation against the heir until it is paid up. Interestingly till date in Ao-Naga society there are several families being crushed in the cycle of debts made by their predecessors. Even the personal possessions like vehicles, lands secured by purchase etc, are sold to meet the purpose.

Position of Ao-Naga women: Ao women enjoy considerable privileges in family and society. They are mentioned as follows:

a) A girl can be named after her father's family but she cannot name her children after her father's family. In the past, except in certain religious offerings which are restricted only to priests women participated in all social and religious activities and also danced together with the opposite sex.

b) A woman cannot inherit property, movable or immovable, though she may be given a gift. She has the right to sell it if she so wishes.

c) If a woman receives immovable property or otherwise from her father in the form of gifts during his lifetime, it remains hers till her death, after which it goes back to her father's heir.

d) On her marriage, her separate property does not merge with that of her husband.

e) She cannot become a member of the Tatar Putu Menden (Village Council).

f) In the past, she could not become a Patir/Putir (Priest) though she may be the oldest person in the village. She is debarred from performing religious rites and sacrifices. However, she can assist her husband in family worship. Earlier, there were medicine women, diviners, tiger women and prophetesses among the womenfolk.

g) She cannot participate in public debates or discussions but can counsel and advise her husband at home to a certain degree.

\section{III}

Sümi woman is referred to as 'Sülimi'. As gleaned from the folktales, one can deduce that Sülimis held a good standing in the society in the past. The higher the talents of a Sülimi, the better prospects she had in the society. But the standing she had in the society was more of the role she played as a wife. The running of the household was shouldered by donning the role of an efficient wife. She played a major role in enhancing the status and power of her husband. In the tale, 'Khakhu and Sheyili', Khakhu was highly regarded by the villagers because of his wife Sheyili. Sheyili was a very generous person who in her capacity as the wife of Khakhu helped the villagers and never turned anyway away from their doorstep empty handed. This was not the case with her mother-in-law who ended up pushing the status of her husband below his own son because of her ill-conduct.

Sülimis had the liberty to voice their choice in front of their parents. In 'Khumutsah-the Orphan', 10 Tüghünakha stood up against her parents for the ill-treatment they melted on Khumutsah only because he was an orphan and was not considered as a suitable suitor. Her parents were left wondering what she saw in him for the way she defended him. In another tale, 'Nisapa and Nisala,, ${ }^{11}$ Nisala went to the extent of quietly handing over her necklace to be sold and used as a bride-price by Nisapa who was from a very poor background. It's a different matter that she was not allowed to marry him because he was delayed in coming back with the bride-price. 
Before marriage, the identity of Sülimi was embodied on who her father was. After marriage, this identity was transferred to who her husband was. In a good number of folktales, one would find the name of her father repeated in the events preceding her marriage. In this stage, her name is taken as it is to narrate the events but, the moments she gets married, she is referred to as the wife of so and so. Her name ceases to appear in the narratives. In 'Thochipa', ${ }^{12}$ Tusholi's name ceases to be used after she got married to Thochipa. She is only referred to as Thochipa's wife in the rest of the folktale. As the tale progresses towards the end, she gets back her name on after the demise of her husband Thochipa.

Sülimis did not have the inheritance right under the patriarchal society. By inheritance here, we mean the ancestral lands. But she was entitled to keep her ornaments and other moveable items including livestock provided it was reared by her. In 'Inakha and Ghonili' ${ }^{13}$, Ghonili left her husband because he had given his word to be married to another woman while still being married to her. She gathered her necklaces, bangles and other articles before leaving her husband's home. Those were regarded as her property and it was at her disposal to be used as she deemed fit.

IV

By studying the Ao and Sümi women, one can discern that both the community shares some similarity as well as differences. Being a patriarchal society women of both the community do not have the right to inherit ancestral or family land/s, that compare the identity of women of these two communities. After marriage, the Ao women do not lost their title after they are married unlike Sümi. For example, if an Ao girl is from a Longchar clan and if she gets married to a Longkumer clan, she will always remain a Longchar till she dies. She gets to retain her clan title where as a Sümi girl has to let go of her clan identity and embrace her husband's clan title. Unlike Ao community, there is a bride price among the Sümi community. The prospective groom is expected to provide bride price as per the status of the bride's father as well as his own. But as of now this practice of giving bride price is diminishing. It is no longer rigidly practice as before.

\section{V}

In the $21^{\text {st }}$ century the Naga women has changed their attitude and the status of the women has been improved to a certain extend. Though there will ever have a strong hold in the status of the women because of the strong cultural dominance and a patriarchal hierarchy but the Naga women are involving in the socio-economic and political scenario in the society. The coming of education has really played an important role among the women wherein they have attained a position and identity within the family and the community. Though there are many social restrictions which is imposed among the women in men dominated society but this does not stopped the Naga women in venturing into new horizon. Today, the Naga women in general and the Aos and the Sümis in particular are creating waves and building new identity in corporate world both national and international, fashion industry, chefs, there are quite a number of academicians, Ph.D holders, doctors, engineers, deacons, youth directors and pastors, musicians, theologians, entrepreneurs, having jobs both in State and Central governments and so forth. The Aos and the Sümi women were never made to feel that they belonged to a weaker sex. The remarked given by Haimendrof regarding Naga women speaks volume when he said, "Many women in more civilized parts of India may well envy the women of the Naga Hills, their high status and their free and happy life; and if you measure the cultural level of a people by a social position and personal freedom of its women, you will think twice before looking down on the Nagas as savages." 14

\section{References:}

\footnotetext{
${ }^{1}$ Information gathered from Rongsenkaba, 77 years old, Yimjenkimong village, interviewed on 10.06.2008

${ }^{2}$ Lucy Zehol, (ed), Women in Naga society, New Delhi, Regency publications, 1998, p. 94

${ }^{3}$ J.P Mills, The Ao Nagas, Kohima, Directorate of Art and Culture, 1926, (reprint 2003).p.90

${ }^{4}$ Information gathered from Longrichila Longchar (F), 78 years, Longkhum village, interviewed on 20.12. 2007

${ }^{5}$ The Mithun (Bos Frontails) exist both in wild and semi-domesticated form. This animal has religious significance and intimate relation with socio-cultural life of the people.

${ }^{6}$ Information gathered from Rev.L.Pona Jamir (M), 77 years, Mopongchuket village, Interviewed on 24.05. 2008

${ }^{7}$ Information gathered from Imtilepzuk Jamir, Interviewed on 24.06.2009, 68 years, Changtongya village.

8 Tajen Ao, Ao Naga Customary Laws, Jorhat, Aowati Imchen, 1980, p.185
} 
${ }^{9}$ H.Salome Kinny. Writing the Self: Working translation into English and Discussion of Sümi-Naga Folktales. Unpublished M.Phil Dissertation submitted to Centre for Applied Linguistics and Translation Studies (CALTS), University of Hyderabad, June, 2006. pp.54-58

${ }^{10}$ Ibid., pp. 59-63

${ }^{11}$ Ibid., pp. 63-69

${ }^{12}$ Ibid., pp.104-107

${ }^{13}$ Ibid., pp.50-53

${ }^{14}$ Haimendorf, C.V.F., The Naked Nagas, London, Methuen, 1944.p.101 